\title{
DETERMINATION OF STATURE FROM THE LENGTH OF MIDDLE FINGER- AN AUTOPSY STUDY
}

\author{
Sheik Shakeer Hussain S1, Ajay Balachandran²
}

${ }^{1}$ Assistant Professor, Department of Forensic Medicine, Government Medical College, Thrissur, Kerala.

${ }^{2}$ Professor, Department of Forensic Medicine, Amrita Institute of Medical Sciences, Amrita University, Kochi, India.

ABSTRACT
BACKGROUND
Estimation of sex and stature from dismembered body parts has not been conducted in the state of Kerala at the time of this study.
There is a need for regression equations to be used in stature estimation for the Kerala state.
The aims of this study is to derive regression formula to estimate the stature from the middle finger length and to device
methods to determine the sex of the deceased from the middle finger length.

\section{MATERIALS AND METHODS}

This is a descriptive study where the length of the middle finger and the stature were measured in 224 dead bodies (167 males and 57 females) of the residents of Kerala, brought for autopsy examination at Thiruvananthapuram Medical College.

Statistical Analysis- Pearson's product-moment coefficient of correlation, multiple correlation analysis (R), paired sample ' $t$ ' test and independent sample t-test (Student t-test) were used.

\section{RESULTS}

The relationship between the stature and middle finger length was statistically analysed and was found to have a very strong association. Regression formula for estimating stature from the length of middle fingers were derived for both sexes. The study also revealed the utility of the measurement in identifying the sex of the individual.

\section{CONCLUSION}

The regression equations derived in this study can be used for the population of Kerala to estimate the stature. A useful method for sex determination has also been devised in this study.

\section{KEYWORDS}

Correlation Coefficients, Hand Measurements, Middle Finger Length, Regression Analysis, Sex Determination, Stature Estimation, T-Test.

HOW TO CITE THIS ARTICLE: Hussain SSS, Balachandran A. Determination of stature from the length of middle finger- an autopsy study. J. Evolution Med. Dent. Sci. 2017;6(70):5009-5012, DOI: 10.14260/Jemds/2017/1088

\section{BACKGROUND}

Establishing the identity of a person is a major concern in Forensic Medicine and Forensic Anthropology. ${ }^{1}$ It is one of the main objectives of any medicolegal autopsy as well. Recovery of unknown bodies either in full or in part as remnants or fragments or bodies in charred or putrefied state is a fairly common affair in medicolegal practice.

The primary characteristics of identity are those of sex, age and stature and they may at once serve to disprove a supposed identity. Most of the body parts bear a more or less constant relationship with stature. Hence, the measurements of body parts are of importance in estimation of stature, especially when only dismembered body fragments are found. The stature of a victim can be estimated when a part of body such as a long bone, hand or foot is all that remains.2,3,4

Despite the relationships between body parameters that have been determined, it is important to remember that these

Financial or Other, Competing Interest: None.

Submission 27-07-2017, Peer Review 19-08-2017,

Acceptance 26-08-2017, Published 31-08-2017.

Corresponding Author:

Dr. Ajay Balachandran,

Professor,

Department of Forensic Medicine,

Amrita Institute of Medical Sciences,

Amrita University,

Kochi-682041, Kerala, India.

E-mail: drajay1976@yahoo.com

DOI: $10.14260 /$ jemds $/ 2017 / 1088$ vary in people belonging to different populations and ethnicities due to differences in genetics, ${ }^{5}$ nutrition and levels of physical activity.6,7,8

Studies have been conducted in many different parts of the world to estimate the stature from the measurements of various body parts. Some studies have focused on the measurements of carpal bones. Jonathan S Musgrave published such a study in 1978, in which the length of metacarpals was measured from radiographs. ${ }^{9}$ A study published by Meadows L in 1992, which used metacarpal bones in the Terry collection as well as modern bones is another example. ${ }^{10}$ These two studies showed a positive association between the length of metacarpals and the stature. Certain other studies have used percutaneous measurements of body parts including middle finger. Attempts to estimate the stature from the length of middle finger was done by MacDonnel ${ }^{11}$ in 1901 . In this study, he used the cubit length (from elbow to tip of middle finger) and the foot length in addition to the middle finger length. He studied 3000 English criminals and derived regression formula for estimation of stature. Of the different regression formulae he derived, the following three involved the length of the middle finger-

1. Stature $=166.45716+7.7849$ (Finger III -11.54737 )

2. Stature $=166.45716-0.6703($ Finger III -11.54737$)+$

2.7886 (Cubit - 45.05864)

3. Stature $=166.45716+2.8360($ Finger III -11.54737$)+$ 3.0304 (Foot - 25.68770) 
In a study published in 2004 , the association between the stature and (i) the distance between the proximal and the middle flexion creases of the middle finger, (ii) the distance between the middle and distal flexion creases of the middle finger and (iii) the distance between the distal phalangeal crease and the tip of middle finger were analysed by Jasuja OP. The subjects were Jat Sikhs. He found that there was a statistically significant association between these measurements and the stature. ${ }^{12}$

Rastogi et al $^{13}$ published a study in 2008 , which analysed the association between lengths of the middle fingers of 500 right handed Indian medical students (230 males and 270 females aged between 20 and 30 years) and their stature to derive a regression equation to predict stature. The study not only yielded different formula for right and left middle fingers and sexes, but also for North Indians and South Indians. However, the differences were insignificant when values were compared between subjects of the same sex in North and South Indians and also between the dominant and nondominant hand. ${ }^{14}$ The regression equations obtained in the study are given in Table 1.

Estimation of sex and stature from dismembered body parts has not been conducted in the state of Kerala at the time of this study. In the opinion of the authors, this study will be useful for forensic pathologists who practice in the state of Kerala in the estimation of stature and determination of sex from dismembered body parts.

\section{MATERIALS AND METHODS}

This descriptive study was conducted between November 2010 and November 2011 in the Department of Forensic Medicine at Medical College, Thiruvananthapuram; 224 dead bodies (167 males and 57 females) of Keralites aged between 20 and 60 years brought for autopsy were included in the study. Only those who are the residents of Kerala were included in the study. Those having any significant congenital or acquired deformities including fractures of spinal column and long bones as well as segmented, charred, mutilated and decomposed bodies were excluded. Those with poorly defined hand creases as well as those with history of nutritional deficiency, abnormal growth pattern and hormonal imbalance were also kept out of the sample.

The measurements were recorded after manually breaking the rigor mortis. All the measurements were taken by the first author to minimise subjective errors-

1. The stature was measured as the straight distance in centimetres from the heel to vertex. To make the measurement, the body is placed on a horizontal surface in supine position in the Frankfurt plane. A wooden block was kept at the foot end to keep the foot straight. Another wooden block was kept parallel to the first one at the head end. The measurement was made using a two-meter-long steel scale fixed to a straight wooden pole, specifically designed for the purpose (Fig. 1).

2. The middle finger length of both hands was measured as the straight distance in millimetres from the midpoint of proximal flexion crease to the tip of the middle finger ${ }^{15}$ using a Mitutoyo Digital Sliding Caliper (accuracy of 0.01 $\mathrm{mm}$ ) with the hand placed in supine position on a flat hard horizontal surface (Fig. 2).
The collected data were analysed using multiple regression analysis to predict sex and stature. As part of regression analysis, Pearson's product-moment coefficient of correlation and multiple correlation analysis (R) were done. In addition, paired sample ' $\mathrm{t}$ ' test and independent sample ' $\mathrm{t}$ ' test (Student t-test) were also applied. The software used for the statistical analysis was SPSS 16.0.

\section{Observations and Analysis}

The measured stature showed the range of $149-185 \mathrm{~cm}$ (mean 165.71) for males and $145-175 \mathrm{~cm}$ (mean 155.39) for females. In males, the range of right middle finger length was $6.57-9.69 \mathrm{~cm}$ (mean 7.7) and left middle finger length was $6.73-9.47 \mathrm{~cm}$ (mean 7.69). In females, the range of right middle finger length was $5.64-7.89 \mathrm{~cm}$ (mean 7.08) and left middle finger length was $5.47-7.81 \mathrm{~cm}$ (mean 7.06). The length of the middle fingers showed significant correlation with the stature for both sexes (see Table 2). The individuals involved in the study were aged between 20 and 60 years. Regression formula were derived for the measurement of stature from middle finger lengths (see Table 3).

The correlation coefficient between stature and right middle finger length is 0.692 in males, which is significant at 0.01 level. The obtained $\mathrm{F}$ value $(\mathrm{F}=151.70 ; \mathrm{p}<0.01)$ is significant at 0.01 level. The correlation coefficient between stature and left middle finger length is 0.666 in males, which is significant at 0.01 level. The obtained $F$ value $(F=131.51 ; p$ $<0.01$ ) is significant at 0.01 level.

The correlation coefficient between stature and right middle finger length is 0.336 in females, which is significant at 0.05 level. The obtained $F$ value $(F=7.00 ; p<0.01)$ is significant at 0.01 level. The correlation coefficient between stature and left middle finger length is 0.344 in females, which is significant at 0.01 level. The obtained $F$ value $(F=$ 7.37; $\mathrm{p}<0.01$ ) is significant at 0.01 level.

The mean right middle finger length and left middle finger length of males and females were compared using paired sample t-test. The t-value obtained is not significant $(t=0.33 ; p>0.05)$ for either the males or the females $(t=0.93$; $\mathrm{p}>0.05)$. There is no significant difference between the lengths of right and left middle fingers in the population studied.

In order to find out whether there exists any significant difference in stature and foot and hand measurements of male and female sample, student $\mathrm{t}$-test was done and the data and results of the analysis are given in Table 4.

From the analysis, it is evident that there is significant difference between males and females with respect to the middle finger length, the males having higher mean values than females. The right middle finger length in males varied from 6.57 to $9.69 \mathrm{~cm}$ and in females it varied from 5.64 to $7.89 \mathrm{~cm}$. The left middle finger length in males varied from 6.73 to $9.47 \mathrm{~cm}$ and in females it varied from 5.47 to $7.81 \mathrm{~cm}$. It is observed that those who have middle finger length less than $6.57 \mathrm{~cm}$ are females and those who have middle finger length more than $7.89 \mathrm{~cm}$ are males. 


\begin{tabular}{|c|c|}
\hline North Indian Males & North Indian Females \\
\hline $\mathrm{H}=117.204+\left(6.820 \times \mathrm{X}_{1}\right)$ & $\mathrm{H}=99.548+\left(8.044 \times \mathrm{X}_{1}\right)$ \\
\hline $\mathrm{H}=113.854+\left(7.223 \times \mathrm{X}_{2}\right)$ & $\mathrm{H}=102.714+\left(7.608 \times \mathrm{X}_{2}\right)$ \\
\hline South Indian Males & South Indian Females \\
\hline $\mathrm{H}=\left(95.901+9.517 \times \mathrm{X}_{1}\right)$ & $\mathrm{H}=\left(110.930+6.517 \times \mathrm{X}_{1}\right)$ \\
$\mathrm{H}=\left(97.400+9.318 \times \mathrm{X}_{2}\right)$ & $\mathrm{H}=\left(112.516+6.321 \times \mathrm{X}_{2}\right)$ \\
\hline \multicolumn{2}{|c|}{ Table 1. Regression Equations to Calculate Stature from Middle Finger Length13 } \\
\hline
\end{tabular}

$\mathrm{H}=$ Height; $\mathrm{X}_{1}=$ the length of right middle finger; $\mathrm{X}_{2}=$ the length of left middle finger.

\begin{tabular}{|c|c|c|c|c|c|c|c|c|}
\hline \multirow[b]{2}{*}{ Parameters } & \multicolumn{4}{|c|}{ Males } & \multicolumn{4}{|c|}{ Females } \\
\hline & $\begin{array}{c}\text { Range } \\
\text { (cm) }\end{array}$ & Mean & $\begin{array}{c}\text { Standard } \\
\text { Deviation }\end{array}$ & $\begin{array}{c}\text { Correlation } \\
\text { Coefficient }\end{array}$ & $\begin{array}{c}\text { Range } \\
\text { (cm) }\end{array}$ & Mean & $\begin{array}{c}\text { Standard } \\
\text { Deviation }\end{array}$ & $\begin{array}{c}\text { Correlation } \\
\text { Coefficient }\end{array}$ \\
\hline Stature & $149-185$ & 165.71 & 7.68 & & $145-175$ & 155.39 & 5.71 & \\
\hline $\begin{array}{l}\text { Right middle } \\
\text { finger length }\end{array}$ & $6.57-9.69$ & 7.70 & 0.51 & $0.692^{*}$ & $5.64-7.89$ & 7.08 & 0.40 & $0.336^{*}$ \\
\hline $\begin{array}{l}\text { Left middle } \\
\text { finger length }\end{array}$ & $6.73-9.47$ & 7.69 & 0.4688 & $0.666^{*}$ & $5.47-7.81$ & 7.06 & 0.39 & $0.344^{*}$ \\
\hline
\end{tabular}

*Significant at 0.01 level

\begin{tabular}{|c|c|c|}
\hline & Males & Females \\
\hline Right middle finger & $\mathrm{H}=84.767+$ & $\mathrm{H}=121.736+$ \\
length & $10.517 \mathrm{X}_{1}$ & $4.750 \mathrm{X}_{1}$ \\
\hline Left middle finger & $\mathrm{H}=81.826+$ & $\mathrm{H}=120.211+$ \\
length & $10.905 \mathrm{X}_{2}$ & $4.980 \mathrm{X}_{2}$ \\
\hline \multicolumn{2}{|c|}{ Table 3. Regression Formula to Calculate Stature from } \\
Middle Finger Length \\
\hline
\end{tabular}

$\mathrm{H}=$ stature; $\mathrm{X}_{1}=$ the length of right middle finger; $\mathrm{X}_{2}=$ the length of left middle finger.

\begin{tabular}{|c|c|c|c|c|}
\hline Parameters & Sex & Mean & SD & t-value \\
\hline \multirow{2}{*}{ Stature } & Male & 165.71 & 7.68 & \multirow{2}{*}{$10.73^{*}$} \\
\hline & Female & 155.39 & 5.71 & \\
\hline \multirow{2}{*}{$\begin{array}{l}\text { Right middle } \\
\text { finger length }\end{array}$} & Male & 7.67 & 0.51 & \multirow{2}{*}{ 9.38* } \\
\hline & Female & 7.08 & 0.40 & \\
\hline \multirow{2}{*}{$\begin{array}{c}\text { Left middle } \\
\text { finger length }\end{array}$} & Male & 7.69 & 0.47 & \multirow{2}{*}{$9.97 *$} \\
\hline & Female & 7.06 & 0.39 & \\
\hline \multicolumn{5}{|c|}{$\begin{array}{c}\text { Table 4. Test of Significance of the Difference between } \\
\text { Means (Student t-test) for the Parameters selected for the } \\
\text { Study }\end{array}$} \\
\hline
\end{tabular}

*Significant at 0.01 level

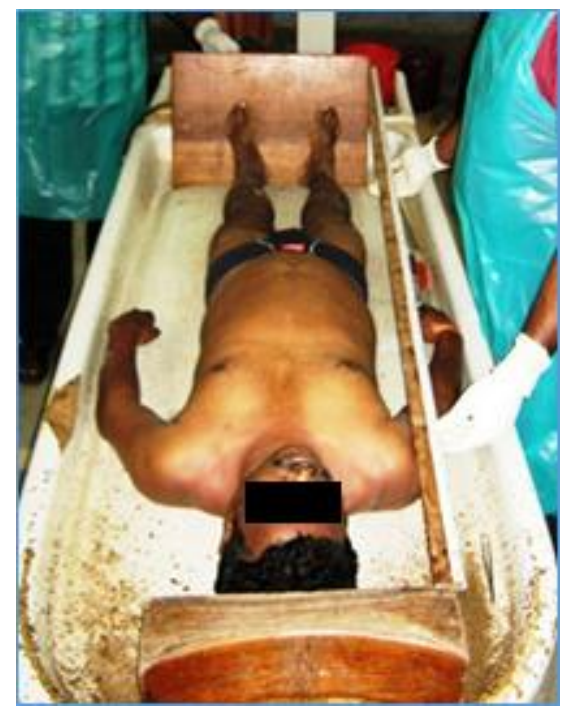

Figure 1. Method of Measuring the Stature

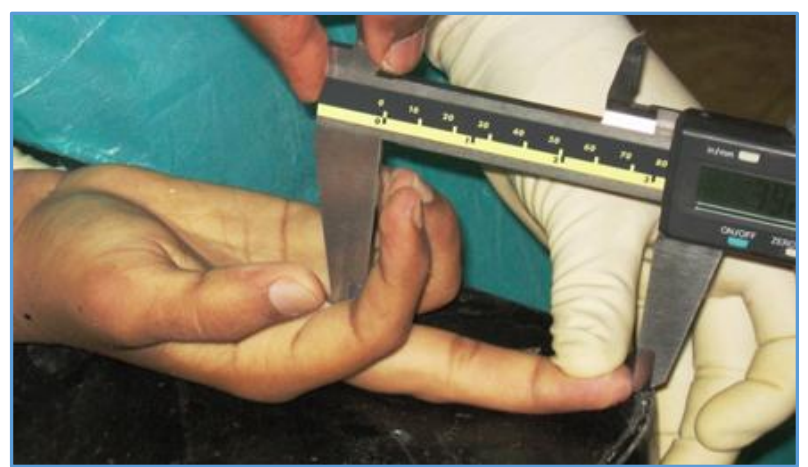

Figure 2. Method of Measuring the Middle Finger Length

\section{DISCUSSION}

Majority of the studies on estimation of stature from hand and foot measurements done previously in India were on live individuals from a particular elite group such as medical students of a very narrow age group, who are not statistically sound representative samples of the general population. The present study was conducted on the dead bodies of Keralites brought for medicolegal autopsy and it naturally involved a cross section of the population and age group.

The measurements were higher in males when compared to the females under study. This finding is in agreement with other published studies. ${ }^{11,13}$ Rastogi et al found significant difference between middle finger length of males and females, which was also observed in the present study. As per the findings of this study, those who have middle finger length of less than $6.57 \mathrm{~cm}$ are females and those who have middle finger length more than $7.89 \mathrm{~cm}$ are males.

To test the applicability of the regression formula derived in this study, they were used in two randomly selected dead bodies brought for autopsy (test cases); one male and the other female. The first test case was a male. From the right middle finger length $(8.12 \mathrm{~cm})$, the stature was estimated to be $170.17 \mathrm{~cm}$ and from the left middle finger length $(7.97$ $\mathrm{cm})$, it was estimated to be $168.74 \mathrm{~cm}$. The actual measured stature of the deceased gentleman was $171 \mathrm{~cm}$.

Similarly, a female dead body was selected as the second test case. From the right middle finger length $(7.1 \mathrm{~cm})$, the 
stature was estimated to be $155.46 \mathrm{~cm}$ and from the left middle finger length $(6.85 \mathrm{~cm})$ it was $154.32 \mathrm{~cm}$. The actual stature of the deceased lady was $157 \mathrm{~cm}$.

This application of the formula in a real-world scenario suggests that a reasonably accurate assessment of stature can be made using the regression equations derived in this study.

\section{CONCLUSION}

As mentioned earlier, the establishment of personal identity in crime investigation is vital. Sex and stature are major parameters required for identification of an individual. In India, regression formula for stature estimation of most of the populations have been derived since the study conducted by Pan in 1924.16 Such data was so far not available for the people of Kerala and this fact underlines the significance of the present study.

It is hoped that the regression equations derived from the present study will be useful in the field of Forensic Medicine in Kerala. It is also hoped that sex determination of the dismembered body parts in mass disasters will also be made easy through the findings of this study.

\section{REFERENCES}

[1] Mathiharan K, Amrit PK. Personal identity. Modi's medical jurisprudence and toxicology. 23rd edn. New Delhi: Lexis Nexis 2006:263-340.

[2] Lundy JK, Feldesman MR. Revised equations for estimating living stature from the long bones of the South African Negro. S Afr J Sci 1987;83:54-5.

[3] Abdel-Malek AK, Ahmed AM, el-Sharkawi SA, et al. Prediction of stature from hand measurements. Forensic Science Int 1990;46(3):181-7.

[4] Ozaslan A, Işcan MY, Ozaslan I, et al. Estimation of stature from body parts. Forensic Sci Int 2003;132(1):40-5.

[5] Jelenkovic A, Hur YM, Sund R, et al. Genetic and environmental influences on adult human height across birth cohorts from 1886 to 1994 . eLIFE 2016;14:5. pii: e20320. doi: 10.7554/eLife.20320.
[6] Malina RM. Physical activity and training: effects on stature and adolescent growth spurt. Med Sci Sports Exerc 1994;26(6):759-66.

[7] Benefice E, Garnier D, Ndiaye G. High levels of habitual physical activity in west African adolescent girls and relationship to maturation, growth and nutritional status: results from a 3-year prospective study. Am J Hum Biol 2001;13(6):808-20.

[8] Damsgaard R, Bencke J, Matthiesen G, et al. Body proportions, body composition and pubertal development of children in competitive sports. Scand J Med Sci Sport 2001;11(1):54-60.

[9] Musgrave JH, Harneja NK. The estimation of adult stature from metacarpal bone length. American Journal of Physical Anthropology 1978;48(1):113-9.

[10] Meadows L, Jantz RL. Estimation of stature from metacarpal lengths. J Forensic Sci 1992;37(1):147-54.

[11] MacDonnel WR. On criminal anthropometry and the identification of criminals. Biometrika 1901;1(2):177227.

[12] Jasuja OP, Singh G. Estimation of stature from hand and phalange length. Journal of Ind Acad Forensic Med 2004;26(3):100-6.

[13] Rastogi P, Nagesh KR, Yoganarasimha K. Estimation of stature from hand dimensions of North and South Indians. Legal Medicine (Tokyo) 2008;10(4):185-9.

[14] Rastogi P, Kanchan T, Menezes RG, et al. Middle finger length--a predictor of stature in the Indian population. Med Sci Law 2009;49(2):123-6.

[15] Kulkarni ML, Rajendran NK. Values for total hand length, palm length and middle finger length in newborns from 26-42 weeks of gestation. Indian Pediatr 1992;29(7):917-9.

[16] Pan N. Length of long bones and their proportion to body height in hindus. J Anat 1924;58(Pt 4):374-8. 